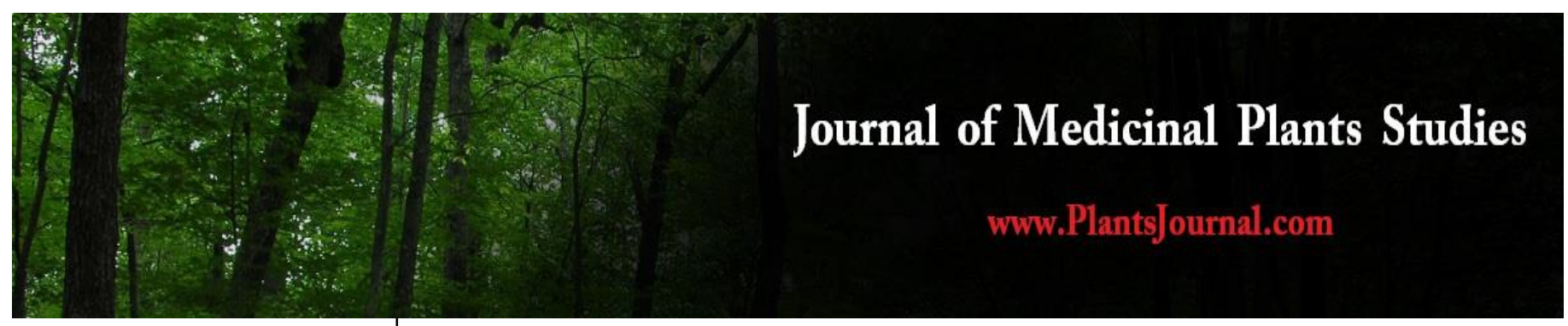

ISSN (E): 2320-3862

ISSN (P): 2394-0530

NAAS Rating: 3.53

www.plantsjournal.com

JMPS 2021; 9(2): 141-145

(C) 2021 JMPS

Received: 17-01-2021

Accepted: 22-02-2021

Jit Narayan Sah

PhD, Office of the Dean,

Institute of Forestry (IOF),

Tribhuvan University, Nepal

Uday Kumar Singh

Institute of Forestry, Pokhara

Campus, Pokhara, Tribhuvan

University, Nepal

Rajan Kumar Sah

Manipal College of Medical

Sciences, Pokhara

Kathmandu University, Nepal

\section{Potential of non-timber forest products in contribution on rural livelihood}

\author{
Jit Narayan Sah, Uday Kumar Singh and Rajan Kumar Sah
}

DOI: $\underline{\text { https://doi.org/10.22271/plants.2021.v9.i2b.1265 }}$

\begin{abstract}
Introduction: Non-Timber Forest Products (NTFPs) are rich sources of forest and contribute of rural livelihoods in fulfilling their subsistence needs and household level income. This research explores the present status of potential NTFPs, influential factor for their collection with contribution for upliftment of rural livelihood.

Methods: The inventory method for bio-physical data and social data for livelihood was used using simple random sampling method.

Result: Seventy-three plant species were recorded with most dominant species at $3000-3300 \mathrm{~m}$ altitude (6923/hectare). Female, illiterate, poor people, aged (>30 years) and people having land holding below five ropani are the main influential socio- demographic and economic factors to collect NTFPs in the study area. Local people have alike opinions about the resource condition of NTFPs.

Conclusion: NTFPs plays a significant role for the subsistence of livelihood of local people. The research will be the fruitful to concerned stakeholders to uplift rural livelihood and enhance entrepreneurship towards NTFPs promotion at local level.
\end{abstract}

Keywords: non-timber forest products (NTFPS), livelihood, Yarsagumba

\section{Introduction}

Forest is the source of livelihood for $95 \%$ of the Nepalese population. The forest plays a crucial role in ecological and economic prosperity of the mountains area watersheds [1, 2]. Various studies reveal that a significant proportion of the world rural population is highly dependent upon forest resources. NTFPs play an important role in the development of the Nepalese economy and in the livelihood of its people. The potential economic value of NTFPs either in terms of utilization or their market value is often underestimated or unknown ${ }^{[3]}$. NTFPs are important tools for addressing poverty issues for the marginalized, forest dependent communities, by contributing to livelihoods, including food security, income, health and sustainable human development ${ }^{[4]}$. Globally, an estimated 350 million people mostly in developing countries depend on NTFPs as their primary source of income, food, nutrition, and medicine ${ }^{[5]}$. These products play a vital role in sustaining the lives of local gatherers, who must increasingly adapt to diminishing resources to stay alive. The challenge is therefore to assess and quantify the value of these products and to transform the use of many of them as are socially and ecologically viable for subsistence and development ${ }^{[6]}$. Hundreds of species are traded and used locally, employing thousands of collectors, village traders and exporters in Nepal [7]. According to Department of Forest (DoF) every year Nepal collects over 25 million rupees as revenue from NTFPs collection and over 160 NTFP plant species are exported from Nepal ${ }^{[8]}$.

The commercialization of NTFPs has been promoted by many researchers, yet the understanding of the NTFPs role in the contribution of livelihood improvement and conservation objectives is hindered by the lack of a clear theoretical framework and a functional typology [9]. The significance of NTFPs in rural livelihood improvement and for subsistence has been established by a number of studies ${ }^{[2,10]}$, but little is known about their collection and marketing dynamics ${ }^{[11]}$. Forests in hills and mountains of Nepal are home to many MAPs.

With commercialization of such plants and opening up of new markets, NTFPs have evolved as an important source of income for many rural communities in Nepal. Rural dwellers especially mountainous regions rely on forest resources and more on NTFPs to support their income. They use forest products for subsistence or for sale in markets. Essential oils are
Corresponding Author: Jit Narayan Sah Institute of Forestry, Office of Dean, Tribhuvan University, Nepal

$$
\sim 141 \sim
$$


extracted from more than 18 plants and the oil worth NRs 8.2 crore was exported to third countries in 2010/2011 [19]. It is estimated that 7000 species of higher value plants exist in Nepal making it the twenty-fifth most species-rich country in the world ${ }^{[13]}$. Nepal hosts nearly 2000 species of potentially useful plants, including medicinal and food plants ${ }^{[14]}$.

About two thirds of the rural population in developing world relies on traditional practitioners and medicinal plants to meet their daily needs ${ }^{[15]}$. Commercial use of NTFPs has played vital role in the sustainable development of rural communities. Sunderlin et al., [2005] put forward three assumptions behind the promotion of NTFPs (1) They are more accessible to rural poor and marginalized communities (2) NTFP harvesting is more benign than timber harvesting (3) Increasing value of NTFP provides incentives for conserving forests. Gauli and Hauser, [2009] [2] argued that pro-poor commercialization of NTFPs in community forestry will deliver optimum benefits to poor users. According to them there are three factors in a NTFP management system that is production, marketing, and benefit sharing. The production level describes the arrangements for managing NTFPs within the forest, the marketing level deals with their marketing within the district, and benefit sharing deals only with NTFP-based pro-poor programs in CFUGs. However, there is a lack of documentation of commercially important medicinal and aromatic plants ${ }^{[2,16]}$. Kunwar and Bussmann, [2008] [17] reviewed 264 studies on ethno-botany, ethnomedicine and diversity of MAPs. They found that $20-28 \%$ of local flora is used as local medicine in Nepal ${ }^{[17]}$. MAPs richness increases with increasing altitude up to $2000 \mathrm{~m}$ and then declines. The temperate and alpine region harbors very highly valued medicinal plants ${ }^{[16]}$.

The objective of this study is to assess the status of potential NTFPs and people's perception towards resource condition, conservation and management.

\section{Materials and Methods}

Study Area: Himali community had been selected in Ghermu VDC, Lamjung district for the study site with consultation of DFO, Rangers and other staffs of the District Forest Office. The district (Latitude: $28^{\circ} 03^{\prime} 19^{\prime \prime}$ to $28^{\circ} 30^{\prime} 38^{\prime \prime} \mathrm{N}$ and Longitude: $84^{\circ} 11^{\prime} 23^{\prime \prime}$ to $84^{\circ} 38^{\prime} 10^{\prime \prime}$ E) covers an area of 1692 sq. $\mathrm{km}$. with an altitude range from $385 \mathrm{~m}$ to $8162 \mathrm{~m}$. The annual temperature is recorded at $14.1-26.7^{\circ} \mathrm{C}$ and the annual precipitation as $2944.23 \mathrm{~mm}^{[18]}$.

Primary data is collected by resource inventory, interview with key informants, household survey, and focused group discussions. Focus group discussions were carried out on forest products, NTFPs collection, extraction, involvement of people, season of collection, marketing and trade pattern, and income from sale of NTFPs. The Households survey was implemented to supplement the findings from key informant interviews. Secondary data was gathered by consulting scientific publication available in IOF library, DOF, DFRS, and CFUGs documentation and other published related paper etc.

Data Analysis was done by descriptive statistics i.e., frequency, average, standard error, confidence interval was used in the form of table and diagrams to present the result concerning status of NTFPs in the study area. Non parametric chi-square test of independent of attribute was used to identify the association between responses of collection of NTFPs with respect to household/respondent characteristics to analyze the social data concerning livelihood.

\section{Result and Discussions}

There are seventy-three NTFPs species found in the study area.

\section{Socio economic characteristics of the respondents}

Different socio-economic variable with different categories were used to obtain the response for the collection of NTFPs which is tabulated in table no. 1

Table 1: Socio economic characteristics, category with percentage value

\begin{tabular}{|c|c|c|c|}
\hline S.N. & Variable & Category & Percentage \\
\hline \multirow{2}{*}{1} & \multirow{2}{*}{ Sex } & Male & 31 \\
\cline { 3 - 4 } & & Female & 69 \\
\hline \multirow{2}{*}{2} & \multirow{2}{*}{ Education } & Illiterate & 73 \\
\cline { 3 - 4 } & \multirow{2}{*}{3} & Literate & 27 \\
\hline \multirow{2}{*}{4} & \multirow{2}{*}{ Well being } & Poor & 63 \\
\cline { 3 - 4 } & \multirow{2}{*}{ Age (Years) } & Non-Poor & 37 \\
\cline { 3 - 4 } & & $>30$ & 56 \\
\hline \multirow{2}{*}{5} & \multirow{2}{*}{ Land holding (Ropani) } & Below 5 & 54 \\
\cline { 3 - 4 } & & Above 5 & 47 \\
\hline
\end{tabular}

The higher occupancy consists of female, illiterate, poor, above 30 years aged and below 5 ropani landholdings

\section{Status of NTFPS with respect to altitude}

The variation of altitude was through $1800 \mathrm{~m}$ to $3900 \mathrm{~m}$ so that there appeared variation of NTFPs in different altitudinal ranges as shown in Figure 1. The maximum numbers of species have been found in the altitude range of 3000-3300 m with 33 percentages. Scatter with smooth lines and markers illustrates that there is no regular pattern of distribution of NTFPs with respect to altitudinal variations. This type of scenario was due to include of all NTFPs in the study.

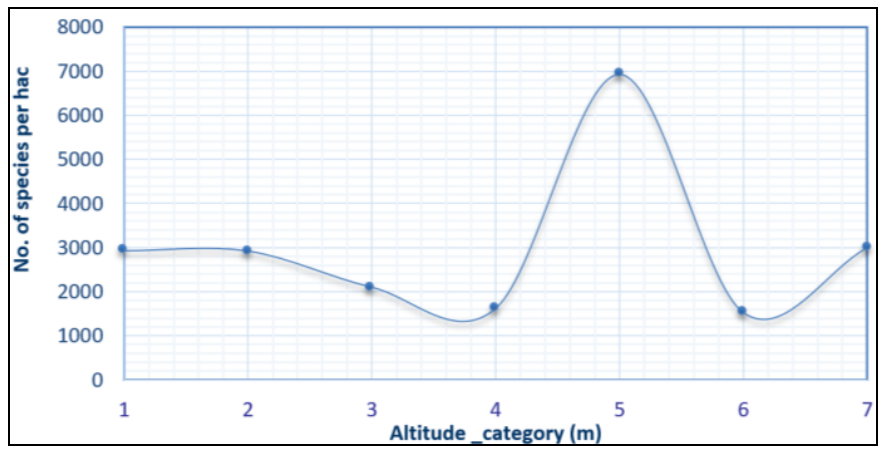

Fig 1: Scatter with smooth lines and markers shows the trends of the NTFPS distribution with altitude

The trend of the numbers of species has decreased with the increase of slope. Listed NTFPS (table 1) occupancy was more favorable at the less sloped area. The decreasing trend has appeared as 150 in numbers per ha from $1^{\text {st }}$ to $2^{\text {nd }}$ and 250 numbers per ha from $2^{\text {nd }}$ to $3^{\text {rd }}$ (table 2). 
Table 2: Summary statistics of the Status of NTFPS with respect to Slope

\begin{tabular}{|c|c|c|c|c|c|}
\hline \multirow{2}{*}{ S.N. } & \multirow{2}{*}{ Slope (Degree) } & \multirow{2}{*}{ Average no./ha } & \multirow{2}{*}{ Std. Error } & \multicolumn{2}{|c|}{ 95\% Confidence Interval for average } \\
\cline { 5 - 6 } & & & & Lower Bound & Upper Bound \\
\hline 1 & $0-20$ & 2765 & 617 & 1521 & 4009 \\
\hline 2 & $20-40$ & 2613 & 542 & 1538 & 3688 \\
\hline 3 & $40-60$ & 2364 & 970 & 352 & 4377 \\
\hline \multicolumn{2}{|c|}{ Pooled Average } & 2619 & 386 & 1857 & 3381 \\
\hline
\end{tabular}

\section{Status of NTFPs with respect to Aspect}

Aspect plays a crucial role in the distribution of NTFPs so that some aspects are more favorable for the growth of NTFPs. Figure 2 portrays that south east aspect has seemed more feasible (38\%) for the growth of NTFPs followed by north west $(32 \%)$ and south west $(30 \%)$ respectively in the study area.

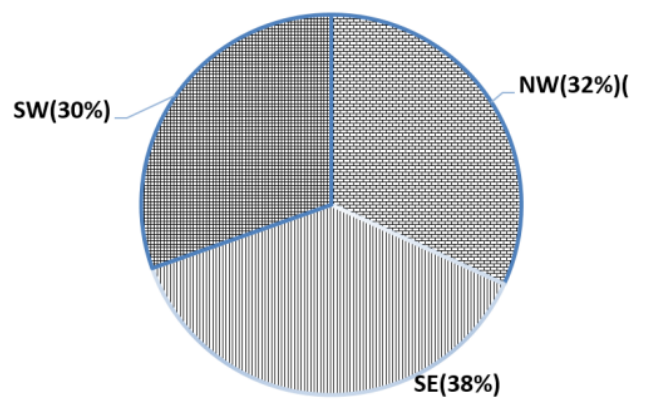

Fig 2: Pie diagram showing the percentage occupancy of NTFPs with respect to Aspect

\section{Status of NTFPs with respect to crown cover}

In generally, crown cover and occupancy of species numbers are inversely proportional in the forest. Figure 3 indicates that the trend of numbers of plants has decreased when crown cover has increased.

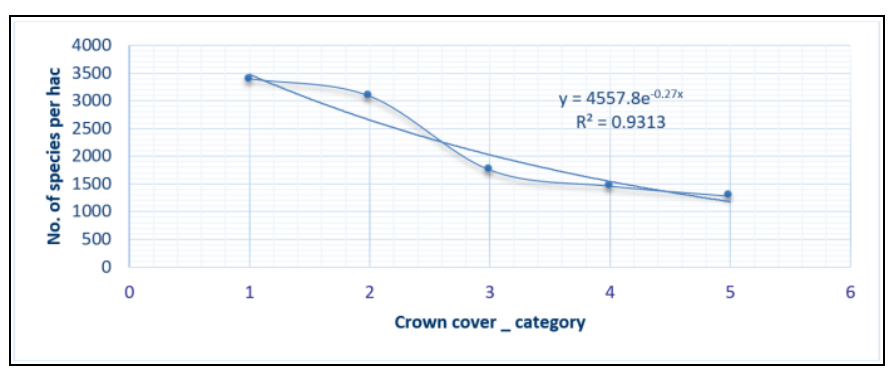

Fig 3: Exponential trend of crown cover and no. of species

The trend of crown cover and no. of species found as exponentially decline with coefficient of determination $\left(\mathrm{R}^{2}\right)$ as 0.93 so that $93 \%$ of the total variation in the number of species has been explained by independent crown cover and variation unexplained by unknown variable depicted in figure 3.

\section{Influencing factors for the collection of NTFPs}

Six variables with two categories in each variable were included to determine the influential factors for the collection of NTFPs. Binary dependent variable with direct answers with "Yes" or "No" were applied to each respondent at household level. Our village settlement is composed of socioeconomic diversification and response of each individual person/ household level varies remarkably with respect to these characteristics.
Table 3: Association between socio-economic characteristics and collection of NTFPs

\begin{tabular}{|c|c|c|c|c|c|c|}
\hline \multirow[t]{2}{*}{ S.N. } & \multirow[t]{2}{*}{ Variable } & \multirow[t]{2}{*}{ Category } & \multicolumn{2}{|c|}{$\begin{array}{c}\text { Response } \\
(\%) \text { on } \\
\text { Collection } \\
\text { of NTFPs }\end{array}$} & \multirow[t]{2}{*}{$\begin{array}{l}\text { Chi- } \\
\text { square } \\
\text { value }\end{array}$} & \multirow[t]{2}{*}{$\begin{array}{c}P \\
\text { value }\end{array}$} \\
\hline & & & Yes & No & & \\
\hline \multirow{2}{*}{1} & \multirow{2}{*}{ Sex } & Male & 42 & 58 & \multirow{2}{*}{9.7} & \multirow{2}{*}{$.002 *$} \\
\hline & & Female & 64 & 36 & & \\
\hline \multirow{2}{*}{2} & \multirow{2}{*}{ Education } & Illiterate & 66 & 34 & \multirow{2}{*}{21.78} & \multirow{2}{*}{$0.00 *$} \\
\hline & & Literate & 33 & 67 & & \\
\hline \multirow{2}{*}{3} & \multirow{2}{*}{$\begin{array}{r}\text { Well } \\
\text { being }\end{array}$} & Poor & 64 & 36 & \multirow{2}{*}{11.54} & \multirow{2}{*}{$0.001 *$} \\
\hline & & Non-Poor & 40 & 60 & & \\
\hline \multirow{2}{*}{4} & \multirow{2}{*}{$\begin{array}{c}\text { Age } \\
\text { (Years) }\end{array}$} & $>30$ & 68 & 32 & \multirow{2}{*}{23.12} & \multirow{2}{*}{$0.01 *$} \\
\hline & & $<30$ & 34 & 66 & & \\
\hline \multirow[b]{2}{*}{5} & \multirow{2}{*}{$\begin{array}{c}\text { Land } \\
\text { holding } \\
\text { (Ropani) }\end{array}$} & Below 5 & 52 & 48 & \multirow[b]{2}{*}{1.46} & \multirow[b]{2}{*}{$0.23^{\mathrm{ns}}$} \\
\hline & & Above 5 & 49 & 51 & & \\
\hline
\end{tabular}

*Significant at $p<0.05$ and $\mathrm{ns}=$ Non significant at $p>0.05$

Out of five applied independent variables, four variables show the association with response of NTFPs collection. Regarding to sex, Females are more likely to involve for the collection of NTFPs than that of male. Non-parametric chi-square test of independent of attributes shows that there is association between sex and NTFPs collection in the study area which is statistically significant $\left(\chi^{2}=9.7, \quad \mathrm{df}=1, \quad \mathrm{p}=.002<0.05\right)$. Similarly, illiterate, poor and more than 30 -year aged people are involved to collect the NTFPs in that area. Nonparametric Chi- square test also proved statistically of these associations $(p<0.05)$. On the other hand, below and above 5 ropani land holding people of that area have equally involved to collect NTFPs so that there are no sufficient evidences to show the association between land holding variable and collection of NTFPs.

Contribution of NTFPs in improving livelihood of people

Forests play important role in poverty reduction and national economic development. They are useful for different purposes and are vitally important, especially for the poorest people in remote areas. NTFPs of the forestry have become a means to increase natural, social, human, financial, and physical capital of community forest users.

From the respondent's perspective, out of total respondents about 31 percent explained as abundant, 35 percent explained as normal and rest 34 percent explained as resource declining day by day. Local people have alike opinions about the resource condition of NTFPs even though somewhat one third people of them claimed that they are declining. The causes of declining indicate the conservation and proper management is urgent need for the species.

Local people perspective on financial contribution of NTFPs on their livelihood

The fund generated from the sale of forest products, tax and other grants are the financial capital created through community forestry. The CF has been providing almost all the production factors to the community. There was no any direct 
money value of Medicinal and aromatic plants (MAPs) obtained in the studied sites. NTFPs contribute to the income indirectly by treating different ailments and thus by saving the money that might have been spent to cure the ailments from modern medical treatments. There is almost equal degree of association between well-being status and degree of satisfaction level. It also portrays that the poor people are slightly dependent on the treatment based on medicinal plants than that of non-poor. Non-parametric chi-square test showed that there was no any indication of disparity of using NTFPs between different wealth rank of local people and their degree of appreciation based on an enormous indirect money value as it treats most of the troubles and diseases.
Financial contribution of some potential MAPs found in the study area

The three potential MAPs i.e., Banlasun, Yarsagumba and Satuwa were taken for the collection as well as trading purpose. There is no any large-scale trading business of these species so that some local traders him/herself or connecting outside contractor performs this activity. Only some households were involved to collect these species for the household purposes and if it is more than that they sold for income purposes and buy others goods for daily household purposes.

Table 4: Summary statistics of financial contribution of some potential MAPs

\begin{tabular}{|c|c|c|c|c|c|}
\hline \multirow{2}{*}{ S.N. } & \multirow{2}{*}{ MAPs Qty and gross income } & \multicolumn{4}{|c|}{ Descriptive statistics } \\
\cline { 3 - 6 } & & Minimum & Maximum & Average value /hh/year & Std. Error \\
\hline 1 & Banlasun_qty (Kg) & 0 & 24 & 3.3 & 1.3 \\
\hline 2 & Banlasun_gross price (NRs) & 0 & 48000 & 6500 & 2696.2 \\
\hline 3 & Yarsagumba_piece (\#) & 0 & 533 & 94.2 & 31.6 \\
\hline 4 & Yarsagumba gross price (NRs) & 0 & 400000 & 22717.4 & 17247.4 \\
\hline 5 & Satuwa_qty (Kg) & 0 & 20 & 2 & 1 \\
\hline 6 & Satuwa_gross_price (NRs) & 0 & 40000 & 3956.5 & 1950.5 \\
\hline
\end{tabular}

Table 4 depicted that highly valuable yarsagumba plays a more significant role for the subsistence of livelihood of local people than that of others. The average gross income per household per year of it was 3.5 and 5.7 times higher than that of Banlasun and satuwa. Besides these three MAPs, Nirmasi, Kutki and other species were collected by the people for their household medical purposes so that they save money to go treat for medical hospitals.

\section{Conclusion}

There are seventy-three NTFPs species found in the study area. The numbers of species per ha varies differently. There is no regular pattern of distribution of NTFPs with respect to altitudinal variations. This type of scenario was due to include of all NTFPs in the study. The maximum numbers of species have been found in the altitude range of 3000-3300 m with 33 percentages. The trend of the numbers of species has decreased with the increase of slope. South east aspect has seemed more feasible (38\%) for the growth of NTFPs. The trend of crown cover and no. of species found as exponentially declining.

We conclude that female, illiterate, poor and more than 30 aged people are the more influential factor to collect NTFPs than that of male, literate, non-poor and less than 30 aged people in that area. Contribution of medicinal plants on the livelihood from the perspective of local people of different well being showed that different components of livelihood heavily depend on economic status of the people. Local people of different economic status perceived that all the MAPs have equal resource condition on the forest and main reasons of declining of NTFPs are due to inappropriate management, encroachment and unknown about the real value of it and followed by premature harvesting, over exploitation and least by free grazing respectively. Medicinal plants contribute to the income indirectly by treating different ailments and thus by saving the money that could be spent to cure the ailments from modern medical treatments. The three potential MAPs i.e., Banlasun, Yarsagumba and Satuwa were taken for the collection as well as trading purpose including Nirmasi and Kutki for household purposes.

\section{Acknowledgement}

It is our great pleasure and honor to express sincere gratitude to SCIFOR Project of Institute of Forestry, Pokhara for providing the requested fund to conduct this research. Our special thanks to Prof. Dr. Krishan Raj Tiwari for his constant support during the research period. We would also like to thank Budh Raj Gurung and community forest user groups for providing official records and permission to conduct our research.

\section{References}

1. Gautam KH. Forestry, politicians and power-perspectives from Nepal's forest policy. Forest Policy and Economics 2006;8(2):175-182.

doi: http://dx.doi.org/10.1016/j.forpol.2004.07.001

2. Gauli K, Hauser M. Pro-poor commercial management of non-timber forest products in Nepal's community forest user groups: factors for success. Mountain Research and Development 2009;29(4):298-307.

3. Wickens GE. Sustainable Management for Non-Wood Forest Products in the Tropics and Subtropics. In: Readings in Sustainable Forest Management. FAO, Rome, 1994, 55-65.

4. Ahenkan A, Boon EK. Enhancing Food Security and Poverty Reduction in Ghana through Non timber Forest Products Farming: Case Study of Sefwi Wiawso District. Munich: GRIN Publishers, 2008

5. UNDP, The Equator Initiative: Money Grows on Trees. Cameroon Series 5, New York: UNDP, 2004.

6. Saulei SM, Aruga JA. The status and prospects of nontimber forest products development in Papua New Guinea. Common w. For. Rev 73, 1994, 97-105

7. Ojha HR. Current policy issues in NTFP development in Nepal. Asia Network for Small-scale Bio-resources. Kathmandu, 2000.

8. Department of Forest. Non-Timber Forest Products Resource Assessment Guidelines, 2012.

9. Belcher B, Ruiz-Perez M, Achdiawan R. Global pattern and trends in the use and management of commercial NTFPs: implication for livelihoods and conservation. World Development 2005;33(9):1435-52. 
10. Shrestha KK, Tiwari NN, Rajbhandari S, Shrestha S, Uprety Y, Poudel RC. Non- timber Forest Products (NTFPs) in the Critical Bottlenecks and Corridors of Terai Arc- Landscape Nepal: Documentation, Utilization, Trade and People's Livelihood. Kathmandu: WWFNepal, 2003.

11. Bista S, Webb EL. Collection and marketing of nontimber forest products in the far western hills of Nepal. Environmental Conservation 2006;33:244-255.

12. Oparaojiaku JO, Ekumankama, Ifenkwe GN. Rural livelihood activities/services performed by community based women organization (CBWOs) in Imo and rivers states, Nigeria. Int. J Agric. Extension Social Dev. 2021;4(1):06-09.

13. Bhuju UR, Shakya PR, Basnet TB, Shrestha S. Nepal Biodiversity Resources Book Kathmandu: United Nationals Environment Programme and Ministry of Environment, Science and Technology, Government of Nepal, 2007.

14. Ghimire SK, Sapkota IB, Oli BR, Prajuli RR. Non-timber Forest products of Nepal Himalaya. Database of Some important Species Mounted Protected Areas of Surrounding Region. WWF Nepal Program, Kathmandu, Nepal, 2008.

15. Kunwar RM, Shrestha KP, Bussmann RW. Traditional herbal medicine in Far-west Nepal: A pharmacological appraisal. J Ethno-biol Ethno-med. 2010;6(1):35.

16. Ghimire SK, Higaki D, Bhattarai TP. Gully erosion in the Siwalik Hills, Nepal: estimation of sediment production from active ephemeral gullies. Earth Surface Processes and Landforms, 2006;31(2):155-65.

17. Kunwar RM, Bussmann RW. Ethno-botany in the Nepal Himalaya. Journal of Ethno-biology and Ethno-medicine 2008;4(1):24.

18. District Profile of Lamjung, 2000.

19. TEPC, Nepal Overseas Trade Statistics, Kathmandu: Trade Promotion and Export Centre; c2011. 